\title{
Statistical analysis of gynecological cancer
}

\author{
Sangeeta Pahwa*, Arshdeep Kaur
}

Department of Obstetrics and Gynaecology, SGRDIMSR, Amritsar, Punjab, India

Received: 15 November 2021

Revised: 06 December 2021

Accepted: 07 December 2021

\author{
*Correspondence: \\ Dr. Sangeeta Pahwa, \\ E-mail: sangeetadr30@gmail.com
}

Copyright: () the author(s), publisher and licensee Medip Academy. This is an open-access article distributed under the terms of the Creative Commons Attribution Non-Commercial License, which permits unrestricted non-commercial use, distribution, and reproduction in any medium, provided the original work is properly cited.

\section{ABSTRACT}

Background: Gynaecologic cancers constitute huge burden of morbidity and mortality all over the world. Statistics on gynaecologic malignancies is deficient. It is the leading cause of death and disability worldwide. In India breast cancer ranks number one followed by cervical cancer. The aim of our study was to establish pattern and incidence of gynaecological malignancy.

Methods: This hospital based study was conducted in Sri Guru Ramdass Institute of medical sciences and research, Amritsar on 282 patients from March 2020 to December 2020. The demographic data of all cancer patients regarding age, clinical presentation, site, staging, histopathology and treatment given was collected and was analysed in tabulated form.

Results: In our study, breast cancer was the commonest malignancy encountered in $46.09 \%$ followed by cervical cancer which constituted $32.26 \%$. Ovarian cancer was diagnosed in $15.24 \%$, endometrial cancer in $3.19 \%$, vulval cancer in $2.12 \%$ and vaginal carcinomas in $1.06 \%$.

Conclusions: Gynaecological cancers are one of the leading causes of cancer related deaths in women worldwide, hence it is important to be aware of various types of malignancies. In our study, cases reported in advanced stages because of lack of education and COVID scenario as patients were reluctant to visit hospitals. So we must continue to provide our gynecologic oncology patient the highest quality of medical care at the same time assuring maximum safety for patients.

Keywords: COVID, Gynaecologic malignancies, Screening, Morbidity and mortality, Prevention, Cervical cancer

\section{INTRODUCTION}

Gynaecological cancers being the commonest cancers in women and it is an important public health issue. As there is lack of awareness regarding screening of breast cancer and cancer cervix, most women report at advanced stages, adversely affecting the prognosis and clinical outcome. World is facing a calamitous crisis in the growing pandemic due to COVID-19. COVID-19 has resulted in significant number of elective surgeries being delayed or cancelled worldwide with an estimated 28 million patients being affected. ${ }^{1}$ Cancer being the second leading cause of death and disability worldwide. In an effort to reduce treatment related morbidity and mortality during the
COVID-19 pandemic, many elective anticancer treatments have been postponed or modified. ${ }^{2}$ Contrary to about three decades ago, cancer was more prevalent in the developed countries but now the burden has shifted significantly to the developing countries like India. Gynaecological cancers are grouped epidemiologically into two categories with respect to etiology. Cervical, vulval and vaginal cancers share certain similarities that they have association with human papillomavirus (HPV) infection and they have long premalignant stages before developing invasive cancer so screening methods provide good opportunity and are very useful in prevention of these carcinomas. Second group is of ovarian, fallopian and corpus cancer which do not have definite etiology. Most cases of ovarian cancer 
occur spontaneously although genetic predisposition and role of ovulation inducing agents cannot be over emphasized. Obesity, diabetes, and hypertension are predisposing factors of endometrial carcinoma and are known as corpus cancer syndrome. Breast cancer has familial tendency as well as association with hormonal therapy. It is estimated that, worldwide, cervical cancer accounts for 487,300 new cases and 269,500 deaths; uterine corpus cancer for 233,300 new cases and 61,400 deaths; ovarian cancer for 230,000 new cases and 140,100 deaths; cancers of vagina, vulva, placenta, and ill-defined sites together constitute 74,900 cases. Around 70,000 new cases of uterine cancers and 75,000 new cases of breast cancers are reported in India every year. ${ }^{3}$ Estimation of cancer burden is valuable for the formulation of policies of cancer control and providing health services. Cervical cancer is the second most common gynaecological malignancy encountered in our country. Since there is a long lead time between atypical changes to the development of invasive cancer, screening and vaccination have the potential to dramatically mitigate the burden of cervical cancer. Formulation and implementation of appropriate national cancer screening and control policies with investment in awareness creation, healthcare infrastructure and human resources development are pivotal to reduce the current burden of these malignancies.

\section{METHODS}

This hospital based study was conducted in Sri Guru Ramdass Institute of Medical Sciences and Research, Amritsar on 282 patients from March 2020 to December 2020 .

\section{Inclusion and exclusion criteria}

Females in the age group 5-85 years were included in the study and patients with any bleeding disorders were excluded.

\section{Methodology}

The demographic data of all cancer patients regarding age, clinical presentation, site, staging, histopathology and treatment given was collected. Detailed history regarding age, parity, past menstrual history, past obstetrical history, and any family history of malignancies was enquired.

Thorough general and systemic examination was done. Followed by per abdomen/per speculum examination/per vaginum examination/per rectal examination. Data so obtained was analyzed statistically and patient were managed accordingly.

\section{Ethical approval}

The study was approved by the institutional ethics committee.

\section{Statistical analysis}

The recorded data was compiled and entered in a spreadsheet computer program (Microsoft excel 2010) and then exported to data editor page of statistical package for the social sciences (SPSS) version 20 (SPSS Inc., Chicago, Illinois, USA). Descriptive statistics included computation of percentages and means.

\section{RESULTS}

A total of 282 patients with gynaecological malignancy were included in the study.

Table 1 denotes the incidence according to the age and site of cancer. Approximately $46.09 \%$ of cases were of breast cancer and cervical cancer constituting $32.26 \%$ followed by ovarian cancer of $15.24 \%$ and uterine cancer of $3.19 \%$. Maximum cases of carcinoma were reported in age group of 51-60. In the age group 1-10, 7 year old female presented with pain abdomen, abdominal distension and was diagnosed as dysgerminoma. A 15 year old patient presented with irregular bleeding per vaginum since past 3 months and was diagnosed as leiomyosarcoma of the cervix.

Maximum age of the patient in our study was 82 year old female who presented with foul smelling discharge and bleeding per vaginum, biopsy revealed squamous cell non keratinizing carcinoma.

Table 1: Age wise distribution of various gynaecological cancer.

\begin{tabular}{|llllll|}
\hline Age groups & CA breast & CA endometrium & CA ovary & CA cervix & CA vulva \\
\hline $\mathbf{1 - 1 0}$ & & 2 & & \\
\hline $\mathbf{1 1 - 2 0}$ & & & & \\
\hline $\mathbf{2 1 - 3 0}$ & 1 & 2 & 8 & \\
\hline $\mathbf{3 1 - 4 0}$ & 14 & 6 & 29 & 1 \\
\hline $\mathbf{4 1 - 5 0}$ & 39 & 3 & 8 & 36 & 2 \\
\hline $\mathbf{5 1 - 6 0}$ & 47 & 5 & 14 & 14 & 2 \\
\hline $\mathbf{6 1 - 7 0}$ & 20 & 1 & 9 & 2 & 1 \\
\hline $\mathbf{7 1 - 8 0}$ & 9 & 2 & 1 & & \\
\hline $\mathbf{8 1 - 9 0}$ & & & & & \\
\hline
\end{tabular}

*Leiomyosarcoma of cervix in 15 year old 
Table 2 illustrates the socioeconomic status of the patient's.

Table 2: Socioeconomic status of the study population.

\begin{tabular}{|ll|}
\hline Socio-economic class & Number of patients \\
\hline Upper class & 18 \\
\hline Upper middle class & 48 \\
\hline Lower middle class & 65 \\
\hline Upper lower class & 69 \\
\hline Lower class & 82 \\
\hline
\end{tabular}

Table 3 illustrates the education status of the patient's. Table 4 is denoting distribution of cases according to clinical presentation. Many patients presented with more than one symptom. Table 5 illustrates stage wise presentation of all the gynecological cancer. Most common stage of presentation of CA breast and CA cervix was stage IIB, CA ovary IIIC, CA endometrium stage II.

Table 6 illustrates management algorithms which is multimodal comprising surgery, radiotherapy and chemotherapy.

Table 3: Education status of the study population.

\begin{tabular}{|ll|}
\hline Education status & Number of patients \\
\hline Post graduate & 15 \\
\hline Graduate & 23 \\
\hline Diploma & 18 \\
\hline Higher secondary & 59 \\
\hline Secondary & 105 \\
\hline Primary & 38 \\
\hline Illiterate & 24 \\
\hline
\end{tabular}

Table 4: Distribution according to presentation.

\begin{tabular}{|c|c|c|c|c|c|}
\hline CA breast & CA cervix & $\begin{array}{l}\text { CA } \\
\text { endometrium }\end{array}$ & CA ovary & CA vagina & CA vulva \\
\hline Breast lump-48 & $\begin{array}{l}\text { Postmenopaus } \\
\text { al bleeding-34 }\end{array}$ & $\begin{array}{l}\text { Postmenopaus } \\
\text { al bleeding-5 }\end{array}$ & $\begin{array}{l}\text { Pain } \\
\text { abdomen-14 }\end{array}$ & $\begin{array}{l}\text { Vaginal } \\
\text { bleeding-2 }\end{array}$ & Vulval mass -2 \\
\hline Pain in breast-18 & $\begin{array}{l}\text { Intermenstrual } \\
\text { bleeding-19 }\end{array}$ & $\begin{array}{l}\text { Abnormal } \\
\text { uterine } \\
\text { bleeding-3 }\end{array}$ & Abdominal fullness-6 & $\begin{array}{l}\text { Vaginal } \\
\text { bleeding }+ \\
\text { discharge-1 }\end{array}$ & $\begin{array}{l}\text { Itching over } \\
\text { vulva-1 }\end{array}$ \\
\hline Nipple discharge-4 & $\begin{array}{l}\text { Vaginal } \\
\text { discharge-5 }\end{array}$ & $\begin{array}{l}\text { Pain abdomen } \\
+ \text { AUB-1 }\end{array}$ & $\begin{array}{l}\text { Urinary or stool } \\
\text { retention, } \\
\text { incontinence, } \\
\text { dysuria-5 }\end{array}$ & & $\begin{array}{l}\text { Vulvar mass + } \\
\text { itching-2 }\end{array}$ \\
\hline Breast lump + pain-26 & $\begin{array}{l}\text { Postcoital } \\
\text { bleeding-12 }\end{array}$ & & $\begin{array}{l}\text { Pain abdomen }+ \\
\text { abdominal fullness-9 }\end{array}$ & & $\begin{array}{l}\text { Vulval } \\
\text { bleeding-1 }\end{array}$ \\
\hline $\begin{array}{l}\text { Breast lump + nipple } \\
\text { discharge-14 }\end{array}$ & $\begin{array}{l}\text { Postmenopaus } \\
\text { al bleeding }+ \\
\text { discharge-11 }\end{array}$ & & $\begin{array}{l}\text { Abdominal fullness }+ \\
\text { urinary or stool } \\
\text { complaints-4 }\end{array}$ & & \\
\hline $\begin{array}{l}\text { Breast lump + nipple } \\
\text { discharge + pain-5 }\end{array}$ & $\begin{array}{l}\text { Intermenstrual } \\
\text { bleeding }+ \\
\text { discharge-10 }\end{array}$ & & $\begin{array}{l}\text { Abdominal fullness + } \\
\text { pain abdomen-5 }\end{array}$ & & \\
\hline \multicolumn{6}{|l|}{ Changes in nipple-3 } \\
\hline \multicolumn{6}{|l|}{$\begin{array}{l}\text { Changes in nipple + } \\
\text { nipple discharge-2 }\end{array}$} \\
\hline \multicolumn{6}{|l|}{ Swelling in axilla-3 } \\
\hline $\begin{array}{l}\text { Swelling in axilla + pain } \\
\text { in breast- } 7\end{array}$ & & & & & \\
\hline
\end{tabular}

Table 5: Stage wise presentation of gynaecological cancer.

\begin{tabular}{|c|c|c|c|c|c|c|c|c|c|c|}
\hline \multirow{2}{*}{$\begin{array}{l}\text { Type of } \\
\text { carcinoma }\end{array}$} & \multicolumn{3}{|c|}{ Stage I } & \multicolumn{2}{|c|}{ Stage II } & \multicolumn{2}{|c|}{ Stage III } & \multicolumn{3}{|c|}{ Stage IV } \\
\hline & $\mathbf{A}$ & B & $\mathbf{C}$ & $\mathbf{A}$ & B & $\mathbf{A}$ & B & $\mathbf{C}$ & $\mathbf{A}$ & B \\
\hline CA breast & 5 & 17 & & 27 & 38 & 12 & 10 & 15 & 6 & \\
\hline CA cervix & 3 & 7 & & 8 & 18 & 11 & 8 & 15 & 16 & 5 \\
\hline CA endometrium & & 2 & & 3 & & & 2 & 1 & 1 & \\
\hline CA ovary & & 1 & 2 & 4 & 6 & 4 & 4 & 13 & 6 & 3 \\
\hline CA vagina & & & & 2 & & & & & 1 & \\
\hline CA vulva & & 2 & & 1 & & & & 2 & 1 & \\
\hline
\end{tabular}


Table 6: Treatment of gynaecological cancer depending upon stage.

\begin{tabular}{|c|c|c|c|c|c|c|c|}
\hline Parameters & $\mathbf{S}$ & $\mathbf{C}$ & $\mathbf{R}$ & $\mathbf{S}+\mathbf{R}$ & $\mathrm{S}+\mathrm{C}$ & $\mathbf{R}+\mathbf{C}$ & $\mathrm{S}+\mathrm{C}+\mathrm{R}$ \\
\hline CA breast & & & & 6 & 80 & & 44 \\
\hline CA cervix & 3 & 1 & & & & 87 & \\
\hline CA ovary & 1 & & & & 42 & & \\
\hline CA endometrium & & & & 5 & & 1 & 3 \\
\hline CA vulva & 3 & & & 3 & & & \\
\hline CA vagina & & & 2 & & & 1 & \\
\hline
\end{tabular}

S- Surgery, C- chemotherapy, R- radiotherapy

\section{DISCUSSION}

The burden of gynaecolgical cancer in our country is huge. There is need of accurate data on cancer and introduction or scaling up of prevention programmes along with detection of cancer as early as possible. In our study $46.09 \%$ cases were of breast cancer, making it the leading group in our study. Second most common was cervical cancer comprising $32.26 \%$, ovarian cancer was $15.24 \%$ followed by uterine cancer of $3.19 \%$, vulval cancer in $2.12 \%$ and vaginal cancer comprised $1.06 \%$.

A study done by Kumar on 58 malignant cases of female reproductive organs, cervical carcinoma emerged as the commonest with $56.9 \%$, followed by endometrial carcinoma $(22.4 \%)$, and ovarian cancers $(15.5 \%)$. The vaginal and vulval cancers were found to be the lowest with $3.4 \%$ and $1.7 \%$ cases respectively. ${ }^{4}$

A study done by Jeph et al in 2017 on 504 patients. Approximately $67.2 \%$ of cases were that of cervical cancer, CA ovary $21.8 \%$,ca endometrium $8 \%$, CA vulva $2.5 \%$ and $\mathrm{CA}$ fallopian tube $0.1 \%$. Most common age group to be affected was 51-60 years $(29.5 \%)$ followed by $61-70$ years $(24.8 \%)$ and $41-50$ years $(23.8 \%) .{ }^{5}$ Most common age group affected is 51-60 year group in our study.

Breast cancer, an increasing public health dilemma, represents a heterogeneous group of diseases and still remains today the leading cancer in women and a major cause of morbidity and mortality worldwide. ${ }^{6}$ As per the GLOBOCAN 2018 statistics, there were a total of 1157294 new cancer cases in the year 2018 in both sexes across all ages in India. Among these, there were 162468 cases of breast cancer with a mortality of 87090 cases. The five-year prevalence across all age groups was 405456 cases. ${ }^{7}$ The median age was 53 as per study conducted by Doval et al and most cases are managed with mastectomy along with axillary lymph node dissection followed by chemotherapy and radiotherapy. ${ }^{8}$ In our study most cases encountered were in 50-60 year age group. One patient in our study presented during lactation period ( 2 months postpartum) who was previously treated for mastitis but on examination peau'd orange was present and trucut biopsy confirmed carcinoma. The most common symptom was lump in breast. Maximum cases in our study were diagnosed at stage IIB and were managed with surgery and chemotherapy in maximum number of cases.
Histopathology of CA breast in our study depicted infiltrating ductal carcinoma $95.38 \%$, lobular carcinoma $2.31 \%$, phylloides tumor, papillary carcinoma, mucinous carcinoma $0.76 \%$ each.

Maximum patients of CA cervix were reported in 51-60 year age group in our study. 34 patients presented with postmenopausal bleeding and 11 patients presented with both postmenopausal bleeding and discharge per vaginum in our study as most common symptoms. A study conducted at tertiary centre in Bihar as retrospective analysis of patients of cervical cancer showed that incidence of carcinoma cervix was more in $4^{\text {th }}$ and $5^{\text {th }}$ decade of women life and most common symptoms were postmenopausal bleeding and abnormal uterine bleeding. ${ }^{9}$ Patients reported in advanced stages in our study and were managed with chemotherapy and radiotherapy. Histopathology of cervical cancer in our study was SCC $81.31 \%$, adenocarcinoma $10.98 \%$, villoglandular carcinoma $3.29 \%$ and adenosquamous, small cell neuroendocrine carcinoma $2.19 \%$ each. Most of the cases were histologically confirmed as Squamous cell carcinoma $81.31 \%$ in our study as seen by Kumar in $66.6 \%$ cases in his study. We encountered a 15 years old girl during the study who presented with bleeding per vaginum and on histopathology leiomyosarcoma of cervix was diagnosed. Reviewing the literature there are very few cases of leiomyoisarcoma cervix and youngest case was of 18 year with pregnancy reported by Whitecombe et al. ${ }^{10}$

Ovarian malignancy constituted $15.11 \%$, with a median age of 45 years. ${ }^{11}$ In our study it was diagnosed in $15.24 \%$ cases and was seen in $14.90 \%$ cases in study done by Agarwal et al. ${ }^{12}$ The presenting complaints of ovarian malignancies are lower pain abdomen and abdominal fullness as are seen in present study. Maximum cases reported in stage IIIC and were managed with surgery and chemotherapy. Histopathology of CA ovary in our study is papillary serous cyst adenocarcinoma $39.5 \%$, serous cystadenocarcinoma $25.5 \%$, mucinous cyst adenocarcinoma $20.9 \%$, clear cell carcinoma $6.9 \%$, teratoma $4.6 \%$, dysgerminoma $2.3 \%$. Surface epithelial tumors are the most common involvement as was evident in this series also. ${ }^{4}$

Uterine carcinoma was encountered in $3.19 \%$ cases. This constituted as low as $4.3 \%$ and $1.9 \%$ in other studies, and adenocarcinoma was found to be the most common malignant tumor, as is encountered in our study in $44.44 \%$ 
cases. ${ }^{13,14} 55.55 \%$ cases in present study were managed with surgery followed by radiotherapy. Histopathology of CA endometrium in our study is adenocarcinoma $44.44 \%$, SCC $22.22 \%$ and endometriod, mucinous carcinoma, clear cell carcinoma $11.11 \%$ each.

Vulval carcinoma was seen in $2.12 \%$ of cases in present study. It was encountered in $2.66 \%$ cases in study done by Agarwal et al. ${ }^{12}$ Traditionally, butterfly incision was used which has now been replaced by triple incision technique for radical vulvectomy with bilateral inguinal lymph node dissection. In our study 65 year old female was treated surgically with wide excision of vulval carcinoma and lymph node dissection. Histopathology of vulvar carcinoma in our study is squamous cell carcinoma in $83.33 \%$, and adenocarcinoma $16.67 \%$.

Vaginal cancer comprised $1.06 \%$ of cases and was seen in $3.44 \%$ of cases in study done by Kumar, squamous cell carcinoma was diagnosed in both the cases one being of moderately differentiated type. They had complaints of frequent micturition and vaginal bleeding as the commonest clinical features. ${ }^{3}$ Radiation therapy is treatment of choice for vaginal carcinoma as was done in our study. Histopathology of CA vagina is SCC in $100 \%$ in present study.

\section{Limitations}

Because of COVID scenario there was delayed follow up of patients, morbidity, mortality and recurrence of disease was not enquired because of lost to follow up.

\section{CONCLUSION}

Gynaecological cancers are one of the leading causes of cancer related deaths in women worldwide, hence it is important to be aware of various types of malignancies. In our study, cases reported in advanced stages because of lack of education and COVID scenario as patients were reluctant to visit hospitals. In adolescent age group in order to enhance early diagnosis and adherence to treatment; health awareness and tailored model of care with multidisciplinary management is the more appropriate option. In antenatal period every pregnant women should be counseled regarding screening. Regular cancer screening can increase the programme effectiveness. Vaccination against HPV should be encouraged. So we conceptualized a concept of two virus (HPV for cervical cancer and COVID-19 virus), two sticks (Ayre spatula for PAP smear and COVID testing) swab) two vaccine (HPV vaccine and COVID vaccine) and it seemed very approachable and relatable for the patients to understand the importance of cervical cancer screening. Health education should be institutionalized using mass media and other culturally acceptable means of community mobilization. Education regarding change in menstrual pattern, foul smelling discharge, breast self-examination, maintenance of vaginal and vulval hygiene, awareness regarding STDs and safe sexual practice should be encouraged. Before Infertility treatment, proper evaluation of cases should be done. Obesity, diabetes, hypertension and polycystic ovary syndrome (PCOS) patient are at increased risk of endometrial CA. Proper counseling and lifestyle modification should be emphasized. Whenever prescribing HRT in menopausal patient; robust history taking regarding ovarian, uterine, colon, pancreatic and urinary tract, breast cancer in family should be taken as one may carry a genetic mutation associated to Lynch syndrome. Genetic testing is now available for BRCA 1 or 2 mutation. In addition, research in developed countries should emphasize feasibility of treatment plans, provision of affordable chemotherapeutic drugs, family therapy, surveillance of cancer survivors, and the vital role of counsellors and social welfare practitioners in the care of cancer. A shift from treatment to prevention of the three major gynaecolgical malignancies is overdue. The traditional approach of secondary or tertiary prevention should be shifted to primary or even primodial prevention. In this special situation we must continue to provide our gynecologic oncology patient the highest quality of medical care at the same time assuring maximum safety for patients.

Funding: No funding sources

Conflict of interest: None declared

Ethical approval: The study was approved by the Institutional Ethics Committee

\section{REFERENCES}

1. COVIDSurg Collaborative. Elective surgery cancellations due to the COVID-19 pandemic: global predictive modelling to inform surgical recovery plans. Br J Surg. 2020;107(11):1440-9.

2. Lara OD, O'Cearbhaill RE, Smith MJ, Sutter ME, Knisely A, McEachron J, Gabor LR, Jee J, Fehniger JE, Lee YC, Isani SS, Wright JD, Pothuri B. COVID19 Outcomes of patients with gynecologic Cancer in New York City. Cancer. 2020;126:4294-303.

3. Uma Devi K. Current status of gynecological cancer care in India. J Gynecol Oncol. 2009;20(2):77-80.

4. Kumar R. Prevalence of female reproductive tract cancer in a teaching hospital of Rohtas District, Bihar, India. Int J Res Med Sci. 2018;6:4058-62.

5. Adreena JV, Garg PK, Mahabole K. Incidence of different malignancies in female genital tract: study in 504 women in rural population. Int J Contemp Med Res. 2017;4(1):284-6.

6. Becker S. A historic and scientific review of breast cancer: The next global healthcare challenge. Int $\mathbf{J}$ Gynaecol Obstet. 2015;131(1):36-9.

7. Ferlay J, Colombet M, Soerjomataram I, Mathers C, Parkin DM, Piñeros M, Znaor A, Bray F. Estimating the global cancer incidence and mortality in 2018: GLOBOCAN sources and methods. Int $\mathbf{J}$ Cancer. 2019;144(8):1941-53.

8. Doval DC, Radhakrishna S, Tripathi R, Kashinath RI, Talwar V, Batra U, et al. A multi-institutional real world data study from India of 3453 non-metastatic 
breast cancer patients undergoing upfront surgery. Sci Rep. 2020;10(1):5886.

9. Kumari A, Pankaj S, Choudhary V, Kumari A, Nazneen S, Kumari J, Kumar S. Retrospective analysis of patients of cervical cancer a tertiary center in Bihar. Indian J Cancer. 2018;55(1):70-3.

10. Dayna D. Whitcombe, Philip T. Valente, Ometeotl M. Acosta, Edward R. Kost Gynecol Oncol Rep. 2016;17:45-8.

11. Bray F, Ferlay J, Laversanne M, et al. Cancer incidence in five continents: inclusion criteria, highlights from Volume $\mathrm{X}$ and the global status of cancer registration. Int J Cancer 2015;137:2060-71.

12. Agarwal S, Malhotra K P, Sinha S, Rajaram S. Profile of gynecologic malignancies reported at a tertiary care center in India over the past decade: Comparative evaluation with international data. Indian J Cancer 2012;49:298-302.

13. Jeph V, Adreena, Garg PK, Mahabole K. Incidence of different malignancies in female genital tract: study in 504 women in rural population. Int $\mathbf{J}$ of Contemporary Med Res. 2017;4(1):284-6.

14. Pradhan M, Dhakal HP, Pun CB, Pradhan S, Dangal G. Gynecological malignancy in BPKMCH, Bharatpur: a retrospective analysis of 321 cases. J Nepal Med Assoc. 2001;40:108-11.

Cite this article as: Pahwa S, Kaur A. Statistical analysis of gynecological cancer. Int J Reprod Contracept Obstet Gynecol 2022;11:130-5. 